University of Nebraska - Lincoln

DigitalCommons@University of Nebraska - Lincoln

\title{
The amphipod Orchomenella pinguis - A potential bioindicator for contamination in the Arctic
}

Lis Bach

Aarhus University, liso@ruc.dk

Valery E. Forbes

University of Nebraska-Lincoln, veforbes@umn.edu

Ingela Dahllöf

Aarhus University

Follow this and additional works at: https://digitalcommons.unl.edu/biosciforbes

Part of the Aquaculture and Fisheries Commons, Other Pharmacology, Toxicology and Environmental Health Commons, Terrestrial and Aquatic Ecology Commons, and the Toxicology Commons

Bach, Lis; Forbes, Valery E.; and Dahllöf, Ingela, "The amphipod Orchomenella pinguis - A potential bioindicator for contamination in the Arctic" (2009). Valery Forbes Publications. 47.

https://digitalcommons.unl.edu/biosciforbes/47

This Article is brought to you for free and open access by the Papers in the Biological Sciences at DigitalCommons@University of Nebraska - Lincoln. It has been accepted for inclusion in Valery Forbes Publications by an authorized administrator of DigitalCommons@University of Nebraska - Lincoln. 


\title{
The amphipod Orchomenella pinguis - A potential bioindicator for contamination in the Arctic
}

\author{
Lis Bach, ${ }^{1,2}$ Valery E. Forbes, ${ }^{2}$ and Ingela Dahllöf ${ }^{1}$ \\ 1. Department of Marine Ecology, National Environmental Research Institute, \\ Aarhus University, Frederiksborgvej 399, DK-40oo Roskilde, Denmark \\ 2. Department of Environmental, Social and Spatial Change, \\ Roskilde University, Universitetsvej 1, DK-40oo Roskilde, Denmark \\ Corresponding author — L. Bach, email liba@dmu.dk,$\underline{\text { liso@ruc.dk }}$
}

\begin{abstract}
Indigenous organisms can be used as bioindicators for effects of contaminants, but no such bioindicator has been established for Arctic areas. Orchomenella pinguis is a benthic amphipod, ubiquitous in the Arctic and can be found in high numbers. We collected $O$. pinguis at sites with different contamination levels. Population characteristics (body length distribution, average dry weight and amphipod organic content) were related to sediment contaminant concentrations, in order to identify suitable endpoints for using this species as a bioindicator. We show that O. pinguis was prevalent in both clean and contaminated areas, easy to sample and that its population characteristics could be linked to both contamination and sediment organic content. We suggest that $O$. pinguis is a suitable bioindicator for the Arctic, but that endpoints such as reproductive effects and phenotypic and genotypic responses are needed together with population characteristics to assess impacts of contamination.
\end{abstract}

Keywords: field study, benthic amphipod, contaminated sediment, Greenland, multivariate statistics

\section{Introduction}

Bioindicators are used to assess effects of contaminants in the environment in monitoring programmes around the world. However, there is no established bioindicator of effects for Arctic marine areas, although the Arctic ecosystem has been suggested to be more vulnerable to contaminants than temperate ones since a disturbance of one species may cascade more easily through the food web due to the lower biodiversity and less complex food webs with fewer trophic levels (Chapman and Riddle, 2005).

It has furthermore been demonstrated that contaminants are deposited in the Arctic through long-range transport (Lockhart, 1995; Riget et al., 2004), and during the last 50 years there has been a structural change in Greenland, leading to a centralized consumer and industrial society resulting in a larger and more concentrated discharge of contaminants. An increasing number of studies has examined possible impacts of such contaminants on Arctic marine organisms from laboratory studies (e.g., Olsen et al., 2007; Petersen and Dahllof, 2007; Camus and Olsen, 2008; Petersen et al., 2008), but only few field studies on effects in the Arctic marine environment have been published (Jorgensen et al., 2006, 2008).

Greenland, as most Arctic areas, is highly reliant on marine ecosystem services given that a large part of the population hunts and fishes locally and since the main part of Greenland's export is based on fisheries. The maintenance of the economy and export is therefore highly dependent on the protection of the local marine environment.

One way to assess effects of contamination is through the use of indicator organisms, which are any biological species or group of species whose function, population or status can be used to determine the state of the ecosystem of which they are a part (Adams, 2005). For organisms to be valuable bioindicators it has been suggested that they occupy important trophic positions or niches, are keystone species, or contribute significantly to the biomass and energy flow in the system (Adams, 2005). Furthermore they should be easy to sample, stationary, have a short generation time, low rate of dispersal and be reasonably tolerant to biotic changes and contamination (Thomas, 1993).

A potential indicator organism for Arctic marine environments is the small benthic amphipod Orchomenella pinguis (Boeck), Lysiannasidae, Gammaridea. In the Arctic food web $O$. pinguis constitutes an important group as a scavenger and forms a major link to the pelagic system as a component of prey items for fish, birds and benthic-feeding mammals such as seals (Conlan, 1994). In general, amphipods conform to the criteria of being relatively sedentary, highly abundant, have a relatively high stress threshold (Duquesne et al., 200o) and have long been applied as sensitive environmental bioindicators (Thomas, 1993). O. pinguis has been shown to be more or less ubiquitous within the Arctic ( Horner and Murphy, 1985; Sainte-Marie, 1986a, 1986b, 1991; Legezynska et al., 2000), is found in large numbers (1535 $\mathrm{m}^{-2}$; Sainte-Marie, 1986b), and is relatively sta- 
tionary within a site (Sainte-Marie, 1986b). It is also likely to be among the first organisms to be affected by contaminants originating from land due to its occurrence in shallow coastal waters. Furthermore, O. pinguis feeds partly on detritus (SainteMarie, 1986b), and lives in close association with sediments as a surface burrower. Since sediments are sinks for contaminants, this species is likely to be highly exposed to contaminants not only from water and food sources, but also via contaminants bound to sediment particles. Thus $O$. pinguis fulfils at least some of the criteria for a suitable bioindicator, however nothing has been reported of its occurrence in relation to contaminants and sediment organic content, or its potential to adapt to such habitats. We therefore collected different populations of $O$. pinguis at sites with different sediment contaminant concentrations and organic content, and this is the first paper describing effects on population characteristics of this species in Greenland. This information is needed to assess the species' potential as a bioindicator and to identify suitable endpoints for measurement.

The study area, Ulkebugten, is a larger bay on the west coast adjacent to Sisimiut, the second largest town in Greenland. Already in the 1920 s and 1930 a fish factory and shipyard were established here, and from the 1960 s the town grew rapidly. There is no sewage treatment, so all wastewater from the $\sim 5500$ inhabitants and industry, including a fish factory and a hospital, is discharged, untreated, directly into the sea. Furthermore, Ulkebugten is heavily trafficked by boating, with a marina used for motorboats and motorized dinghies, and a larger harbor with motorized dinghies as well as larger fishing boats, and trawlers. Ferries and cruise ships also frequently anchor in Ulkebugten during the summer season.

The objective of our work was to determine if $O$. pinguis has the potential to serve as a bioindicator for contamination in the Arctic by (i) investigating its occurrence in contaminated areas; (ii) assessing whether living in contaminated areas has any effect in terms of population characteristics of the species; and (iii) suggesting suitable endpoints for detecting contaminant effects.

\section{Materials and methods}

\subsection{Locations and sampling}

Sampling was conducted over three years on four occasions: October 2006, August 2007, May and August 2008 in Ulkebugten, an open fjord in Sisimiut in West Greenland at 5-15 m depth (Table 1). Sampling locations were selected at different sites presumed to have different contamination levels based on previous pilot studies and knowledge of local contamination sources (Figure 1). However, only sites 1-3 were sampled in October 2006.

Amphipod populations were collected using simple baited traps (cylindrical closed netting of about $70 \mathrm{~cm}$ in height and $40 \mathrm{~cm}$ in diameter). The traps were constructed in a way that the trap was pressed flat when being sunk down to the sea floor and after a given collection time (overnight), the trap unfolded when ropes tied to a buoy at the water surface were pulled, so that the organisms were trapped when the netting was pulled to the surface. Bait consisted of 2-3 day old fish mounted directly in the traps. After sampling, the amphipods were kept in

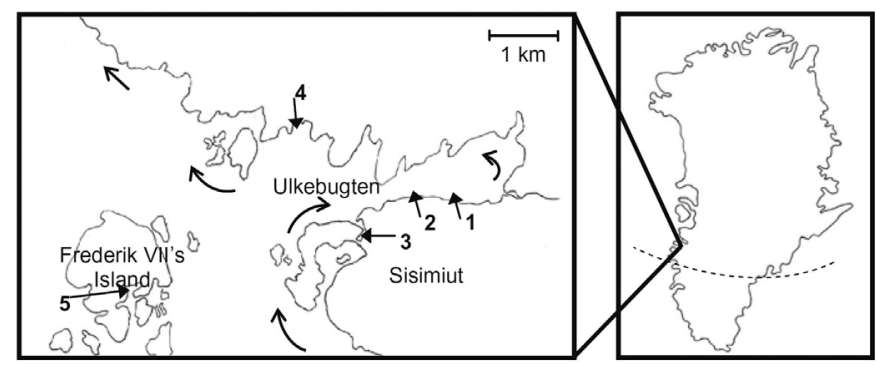

Figure 1. Sampling locations in Ulkebugten, Sisimiut, Greenland. The sampling locations are, from the inner part of the fjord to open waters the three sites closest to point sources 1: hospital wastewater outlet, 2 : marina, and 3: harbor; one site 4: outer bay (outside town, but close to the small airport), and finally a site characterized by the open water masses, 5: Frederik VII's Island.

large buckets (10 1) at $5{ }^{\circ} \mathrm{C}$ in aerated seawater provided with a handful of sediment and a bit of macroalgae until processing.

Sediment was collected using a Van Veen grab at each site on each sampling occasion. After sampling the sediment was drained of overlying water and stored at $-20^{\circ} \mathrm{C}$ until analysis.

\subsection{Sediment analyses}

Analyses included measurements of organic content, 19 PAHs and six heavy metals. The organic content of the sediment samples were determined as loss on ignition at $550^{\circ} \mathrm{C}$ after $6 \mathrm{~h}$.

$\mathrm{PAH}$ analysis was performed according to the method described by Boll et al. (2008) with minor modifications. Mixtures of 18 individual PAHs (PAH mix 2, Supelco); i.e., the 16 PAHs suggested by the US-EPA as priority pollutants, and 1- and 2-methylnaphtalene were used as quantification standards. An internal standard consisting of a mixture of six different deutorated standards in toluene (Cambridge Isotope Laboratories, UK) was used as recovery standard. For estimation of extraction efficiency, replicate reference sediment samples with known $\mathrm{PAH}$-concentrations were included. Briefly, extraction of sediment (approximately $5 \mathrm{~g}$ ) was performed by pressurized liquid extraction with a Dionex ASE 200 accelerated solvent extractor using dichloromethane as solvent under a pressure of $1500 \psi$ and a temperature of $100{ }^{\circ} \mathrm{C}$; the oven heat-up time was $5 \mathrm{~min}$ and the program had two extraction cycles with 15 min static time and a flush volume of $35 \%$. After extraction the samples were concentrated at $75{ }^{\circ} \mathrm{C}$ to approximately $5 \mathrm{ml}$ and transferred to a volumetric flask and filled with dichloromethane to $10 \mathrm{ml}$. Extracts were stored in dark vials at $-20{ }^{\circ} \mathrm{C}$ until analysis. PAHs were analyzed by GC/MS using a Thermo Finnigan TRACE Ultra GC-DSQ MS equipped with a J\&W PH-5MS capillary column (6o m, $0.25 \mathrm{~mm}$ i.d., $0.25 \mu \mathrm{m}$ film thickness). Samples were analyzed using selected ion monitoring, the dwell time was $25 \mathrm{~ms} /$ ion and ion source temperature was $250{ }^{\circ} \mathrm{C}$. The GC temperature program used was as follows: isothermal at $35^{\circ} \mathrm{C}$ for $2 \mathrm{~min}$, $20^{\circ} \mathrm{C} / \mathrm{min}$ to $100{ }^{\circ} \mathrm{C}, 5{ }^{\circ} \mathrm{C} / \mathrm{min}$ to $315^{\circ} \mathrm{C}$ for $15 \mathrm{~min}$. The GC used a PTV injector in splitless mode. Concentrations of the PAHs were classified as not detected/under detection limit when peak detection was less than peaks for the lowest standard (i.e., $1.28 \mathrm{ng} /$ $\mathrm{ml})$. Recovery of reference material $(n=4)$ was $83-135 \%$, except

Table 1. Sampling sites, GPS positions and sampling occasions.

\begin{tabular}{|c|c|c|c|c|c|}
\hline & & 2006/October & 2007/August & 2008/May & 2008/August \\
\hline (2) Marina & $66^{\circ} \mathrm{N} 56.611-53^{\circ} \mathrm{W} 39.528$ & + & + & + & + \\
\hline (4) Outer Bay & $66^{\circ} \mathrm{N} 56.529-53^{\circ} \mathrm{W} 41.229$ & - & + & + & + \\
\hline (5) Frederik VII's & $66^{\circ} \mathrm{N} 55.857-55^{\circ} \mathrm{W} 45.447$ & - & + & + & + \\
\hline
\end{tabular}


for acenaphthylene which showed a recovery of $374 \%$ and was therefore left out of the analysis of contaminant levels.

The concentrations of heavy metals in sediments were analyzed after pre-treatment as described in Danish Standard 259 "Determination of metals in water, sludge and sediments-General guidelines for determination by atomic absorption spectrophotometry." Laboratory procedures and quality assurance followed accredited methods and included microwave digestion followed by analysis on an Agilent 750oce inductively coupled plasma mass spectrometer (ICP-MS) operated according to the USEPA (1994) and Perkin-Elmer 510oPC with FIMS atomic absorption techniques for $\mathrm{Zn}, \mathrm{Cu}$ (air/acetylene flame AA), Cd (graphite furnace AA) and $\mathrm{Hg}$ (flow injection cold vapor AA), all according to Perkin-Elmer standard setup. All methods used external standard curves. Detection limits for metals ranged from 0.01 to $10 \mathrm{mg} / \mathrm{kg}$ dry weight. For every 10 samples, a quality control sample of freeze-dried sediment (MESS-3 from National Research Council, Canada) was run. Recoveries of reference material were $85-115 \%$ and relative standard deviations (RSD) $1-5 \%$, except for $\mathrm{Pb}$ with a low recovery $(77 \%)$ and high RSD for As $(12 \%)$ and $\mathrm{Cd}(18 \%)$ for six digests.

\subsection{Population analyses}

Amphipods from each site were analyzed for body length, dry weight, and organic content. Newly hatched juveniles and egg/juvenile carrying females were removed, which made the analyzed populations consist of older juveniles (body length $>2.5 \mathrm{~mm}$ ), non-gravid females and males. Although the sexes were not separated in the analyses, females appeared larger (personal observation). Size was measured on each individual $(n=200)$ whereas weight and organic content were measured on amphipods placed in groups of five $(n=40)$. A picture of each sample group was taken using a stereomicroscope with a camera attached for later measurements of individual body length $(\mathrm{L}, \mathrm{mm})$ using an image analysis program (SigmaScan Pro vers. 5.o.o). Length of individuals was measured along their dorsal surface from the rostrum to the telson. The samples were then placed on a small piece of preweighed foil and left to dry at $55^{\circ} \mathrm{C}$ overnight for dry weight measurements, after which they were left at $550{ }^{\circ} \mathrm{C}$ for $6 \mathrm{~h}$ for measurements of organic content as loss on ignition.

\subsection{Statistics}

Differences between sites and sampling occasions for amphipod length, dry weight and organic content were tested by the non-parametric Kruskal-Wallis test since assumptions of normality and homogeneity of variances could not be met. Differentiation between sites with respect to population characteristics and level of contamination was described by Partial Least Square (PLS) analysis. Population characteristics were normalized to organic content in the sediment ( $Y$-variables), while contaminant concentrations were log-transformed ( $X$-variables). All data were standardized by $1 /$ std to account for different units and scales. Martens' uncertainty analysis was used to determine significant differences between sites (Martens and Martens, 2000). All statistical analyses were conducted using Statistica 8, SYSTAT 11.o and Unscrambler 8.o.

\section{Results}

\subsection{Site characterization}

The sediment contamination levels at the sites were estimated by measurements of 18 PAHs and six heavy metals (Table 2), though acknowledging that other groups of contaminants also may occur at the sites. For example pharmaceuticals and household chemicals are likely to be discharged at the wastewater outlet by the hospital site, and anti-fouling paint products are likely to occur to a higher extent in the marina and harbor.

The harbor site contained PAHs at a magnitude 10 times higher than the second most contaminated site with a PAH sum of $\sim 13,000 \mu \mathrm{g} / \mathrm{kg}$ at the harbor, and $\sim 1000 \mu \mathrm{g} / \mathrm{kg}$ at the hospital outlet, respectively. The marina was less contaminated (PAH sum of $\sim 300 \mu \mathrm{g} / \mathrm{kg}$ ), whereas both the outer bay and Frederik VII's Island were contaminated with PAHs to a much lower degree with PAH sums of 20 and $8 \mu \mathrm{g} / \mathrm{kg}$, respectively. The harbor site was mostly contaminated with the larger PAHs ( $>4$ ringed), with highest concentrations of fluoranthene, pyrene and benzo $[b+j+k]$ fluoranthene, whereas PAH contamination at the outer bay to a great extent was caused by naphthalene and to a lesser extent by 1- and 2-methylnaphthalene. These compounds are 2-ringed PAHs and are most likely a result of jet fuel runoff from the runway at the airport close by.

The harbor was also the site most contaminated with heavy metals at $\sim 400 \mu \mathrm{g} / \mathrm{kg}$. A large fraction of the metal contamination was by zinc and copper, which made up $50 \%$ and $30 \%$ of the total metal levels at this site. The hospital was the second most contaminated site with regard to heavy metals, followed by the marina, Frederik VII's Island and the outer bay. However, at the two latter sites $\mathrm{Zn}$ made up $71 \%$ and $60 \%$ of the heavy metals. In general the differences in metal concentrations between the sites were not as great as the differences in PAH-concentrations.

The sediment organic content (Table 2) varied to a small extent within sites between sampling occasions, but to a greater extent between the sites, where the harbor and hospital sites had the highest organic content. The organic content of the sediment samples was reflected in the color and grain size, where the sites with the higher organic content had the smaller grain size, higher silt content and darker sediment (Table 2).

\subsection{Population characterization}

The amphipod species $O$. pinguis responded at most sampling occasions rapidly and in large numbers (5-10,0oo individuals) to the bait placed on the seafloor, except for May 2008 where we did not succeed in sampling $O$. pinguis at the marina. Each catch was occupied by this species only, except at the Frederik VII's Island site where amphipods of the species Onisimus sp. co-occurred in the traps. The great number of amphipods collected in each trap is assumed to be a good reflection of the actual population and reflected a high density of the species. With a single box-core sample taken in the middle of Ulkebugten the density was determined to be as high as $9000 \mathrm{~m}^{-2}$ (own observation August 2008).

In October 2006 amphipods were only sampled at the hospital, marina and harbor sites. A comparison of the individual body length of these three populations showed that the populations in the marina and in the harbor consisted of larger juveniles ( 4 and $4.5 \mathrm{~mm}$, respectively), whereas the population at the hospital outlet consisted of two cohorts i.e., both juveniles $(4.5 \mathrm{~mm})$ and larger adults $(9 \mathrm{~mm})$. This is in agreement with observations made on juveniles being released from the brood plates in May 2008, August 2007 and 2008.

The length distribution of amphipods (Figure 2) for the three occasions when all sites were sampled differed both between sites and between sampling occasions (Kruskal-Wallis: $p<0.05$ ). It should be noted that $O$. pinguis could not be caught in enough numbers at the marina in May 2008, despite a large sampling effort. The harbor population was the largest on all three occasions, while the two cleaner sites, Frederik VII's Island and the outer bay, had different length distributions on all occasions, which was not the case for the two moderately contaminated sites (hospital and marina). 
Table 2. Sediment characteristics. Average measurements of three samplings (October 2006, August 2007 and 2008): organic content (\%), PAHs ( $\mu$ g/ $\mathrm{kg})$, metals $(\mathrm{mg} / \mathrm{kg})$ and sums of these at the five sites.

\begin{tabular}{|c|c|c|c|c|c|}
\hline & Hospital & Marina & Harbor & Outer bay & Frederik VII's Island \\
\hline Sediment grain size & Silty & Small grained & Silty & Grained & Grained \\
\hline Sediment color & Dark/black & Dark grey & Black & Grey & Grey \\
\hline Organic content & 4.0 & 1.7 & 5.6 & 0.8 & 1.1 \\
\hline Naphthalene & $9 \cdot 9$ & 7.8 & 179.0 & 10.4 & 1.5 \\
\hline 2-Methylnaphthalene & 20.8 & 6.7 & 171.4 & 3.2 & 1.0 \\
\hline 1-Methylnaphthalene & $9 \cdot 3$ & 4.1 & 88.3 & 3.0 & 0.7 \\
\hline Acenaphthene & 16.3 & 2.7 & 206.9 & 0.0 & 0.3 \\
\hline Fluorene & $4 \cdot 3$ & 3.7 & $197 \cdot 3$ & 0.5 & 0.4 \\
\hline Phenanthrene & 82.5 & 21.3 & 1362.4 & 1.4 & 1.0 \\
\hline Anthracene & 77.0 & 8.8 & 498.7 & 0.1 & 0.3 \\
\hline Fluoranthene & 156.2 & 35.8 & 2378.9 & 0.5 & 1.0 \\
\hline Pyrene & 116.7 & 28.2 & 1872.0 & 0.5 & 0.8 \\
\hline Benzo[a]anthracene & 50.2 & $13 \cdot 3$ & 883.4 & 0.0 & 0.0 \\
\hline Chrysene & 58.7 & 22.8 & 891.0 & 0.0 & 0.1 \\
\hline Benzo $[b+j+k]$ fluoranthene & 156.1 & $57 \cdot 3$ & 1805.4 & 0.0 & 0.6 \\
\hline Benzo $[a]$ pyrene & 86.9 & 30.0 & 871.9 & 0.0 & 0.3 \\
\hline Indeno $[1,2,3-c, d]$ pyrene & 97.2 & 9.8 & 570.7 & 0.0 & 0.1 \\
\hline Dibenzo $[a, h]$ anthracene & 58.0 & $5 \cdot 3$ & 312.2 & 0.0 & 0.0 \\
\hline Benzo $[g, h, i]$ perylene & 49.6 & 28.1 & 577.1 & 0.0 & 0.1 \\
\hline Sum PAHs & $1049 \cdot 4$ & 285.7 & 12866.3 & 19.6 & 8.2 \\
\hline Copper & 22.9 & 12.1 & 131.0 & 5.7 & 6.0 \\
\hline Zink & 41.7 & 26.0 & 197.5 & 21.7 & 32.3 \\
\hline Arsenic & $17 \cdot 4$ & 9.0 & 13.8 & 7.2 & 5.8 \\
\hline Cadmium & 0.4 & 0.1 & 0.6 & 0.1 & 0.1 \\
\hline Mercury & 0.2 & 0.0 & 0.4 & 0.0 & 0.0 \\
\hline Lead & 6.3 & 3.2 & 33.1 & 1.3 & 1.3 \\
\hline Sum metals & 88.9 & 50.4 & 376.4 & $35 \cdot 7$ & $45 \cdot 5$ \\
\hline
\end{tabular}

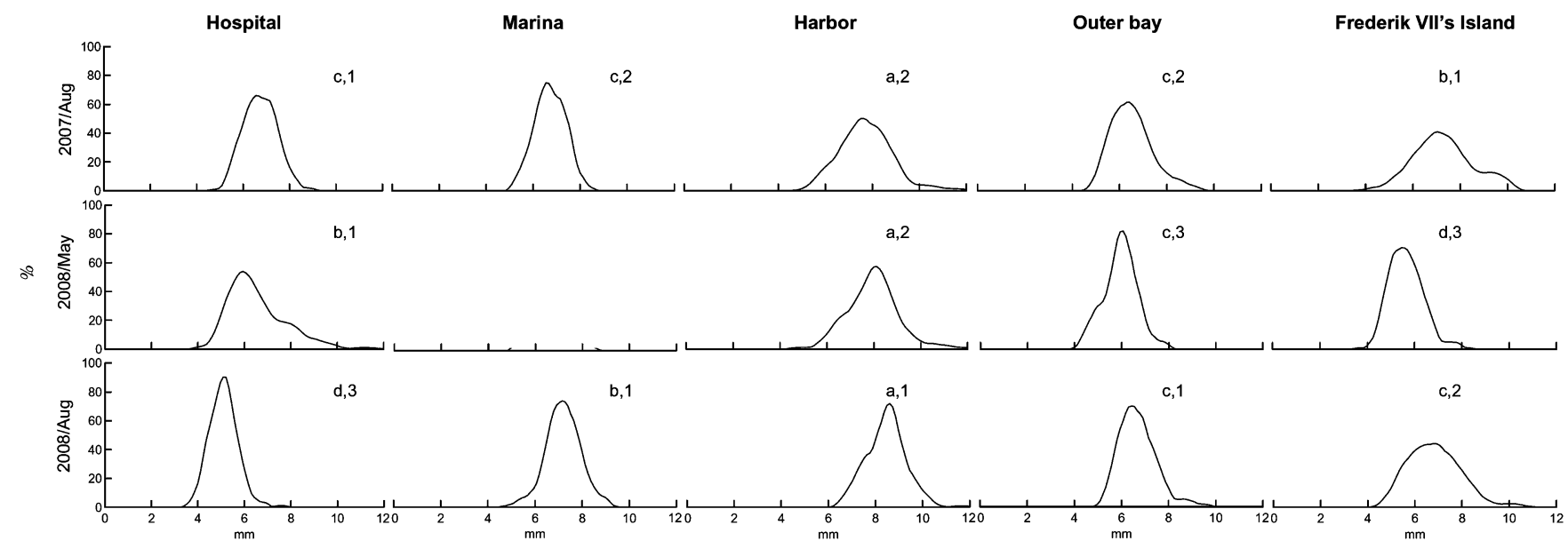

Figure 2. Size distribution (individual body length; $\mathrm{mm}$ ) of $O$. pinguis in populations collected at five sites and on three sampling occasions $(n=200$ ). Different letters indicate significant differences $(p<0.05$, Kruskal-Wallis) between sites within the sampling occasion (horizontal), whereas different numbers indicate significant differences between years within a site (vertical).

Therefore, when relating population characteristics to contamination level, which is more constant over time compared to population dynamics; length, weight, organic content and density of the different years were pooled within the populations, thus giving a time-integrated description of the population including several possible cohorts (Figure 3).

The harbor population was significantly larger for all integrated population characteristics (Figure 4a-d; Kruskal-Wallis: $p<0.05)$. The populations from the most and second most contaminated sites, the harbor and the hospital, differed markedly in most population characteristics, where the population from the harbor was the largest; the one from the hospital was the smallest, with the marina and the two reference sites in between (outer bay and Fredrik VII's Island).
In order to investigate whether these differences in population characteristics could be linked to contamination levels, a PLS analysis was performed where the X-matrix consisted of log-transformed sediment contaminant concentrations and the population characteristics were normalized to $1 \%$ sediment organic matter, thereby correcting for differences in food availability among sites. The model could explain $87 \%$ of the variation in population characteristics based on the contamination matrix, and there was clear separation of the contaminated sites, as well as between the contaminated (hospital, marina and harbor) and the reference sites (Frederik VII's Island and the outer bay) (Figure 4a). The contaminated sites were more characterized by maximum and minimum values for the population characteristics compared to the reference sites (Figure $4 \mathrm{~b}$ ). The harbor was by far the most 

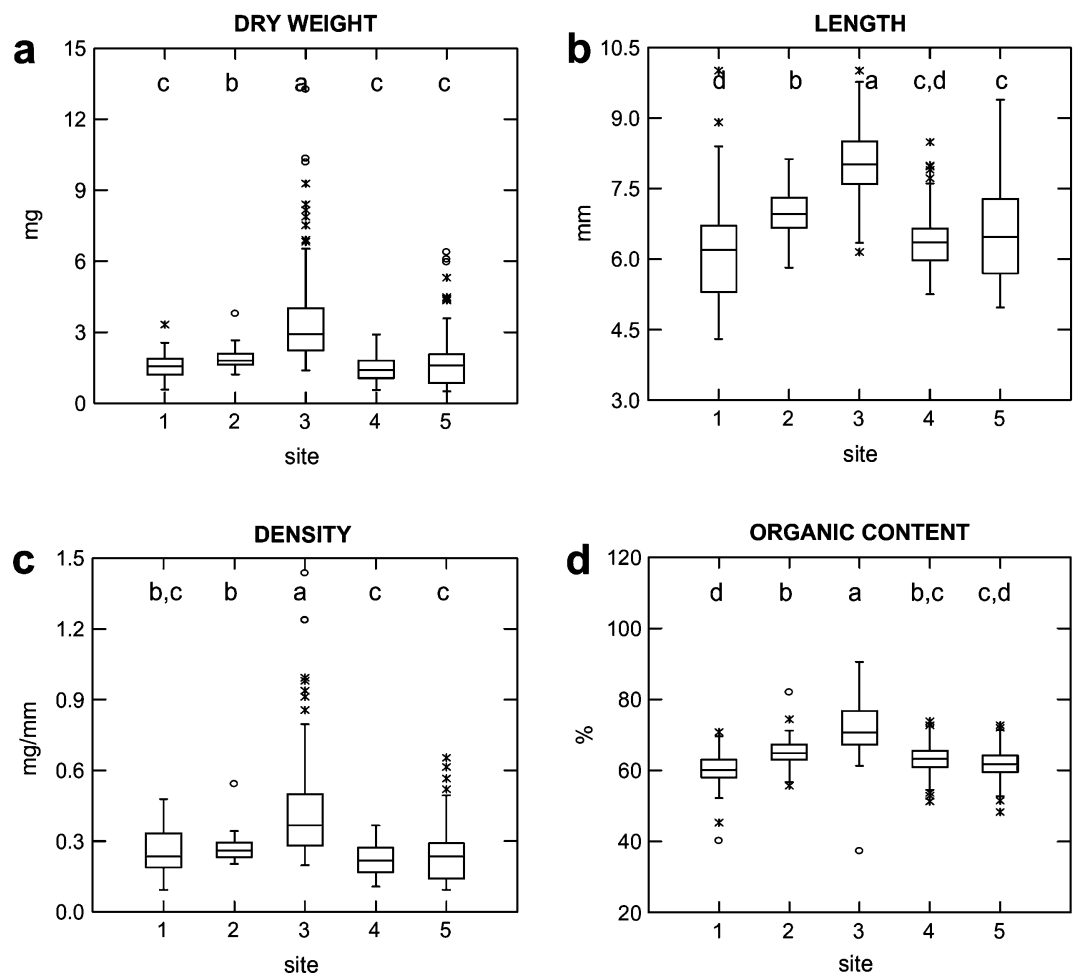

Figure 3. Box plots displaying integrated descriptive parameters for populations collected at site 1: hospital outlet, 2: marina, 3: harbor, 4: outer bay and 5: Frederik VII's Island. (a) Dry weight $(\mathrm{mg})$, (b) length $(\mathrm{mm})$, (c) density (mg dry weight $/ \mathrm{mm})$, and (d) organic content (\% dw). Sites with a letter in common are not significantly different ( $p>0.05$ Kruskal-Wallis).
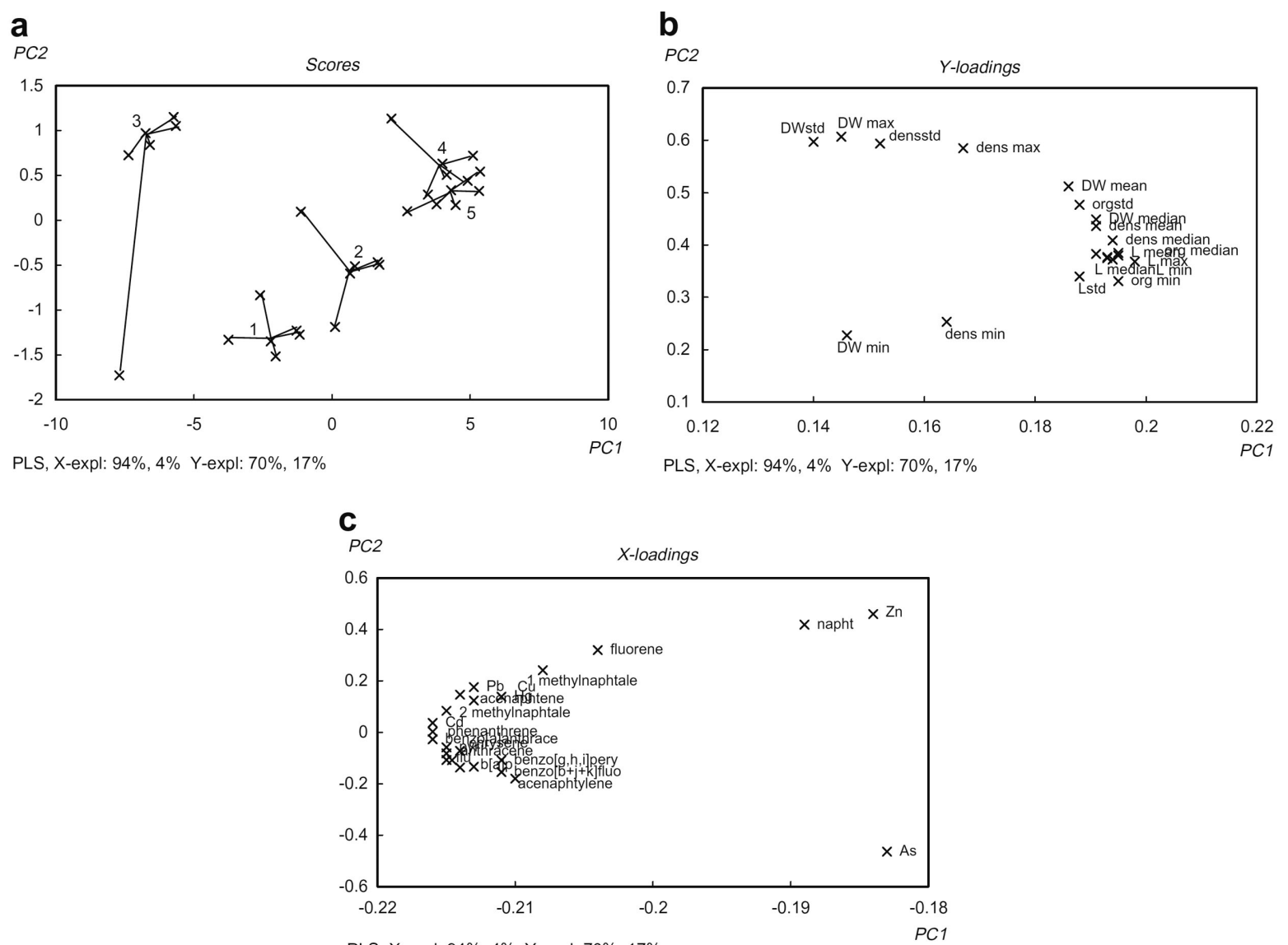

Figure 4. (a) Partial Least Square analysis of the relation between sites, based on (b) normalized population characteristics as explained by (c) the contamination level. Variation within sites in (a) is given by the Martens' uncertainty test. 
a

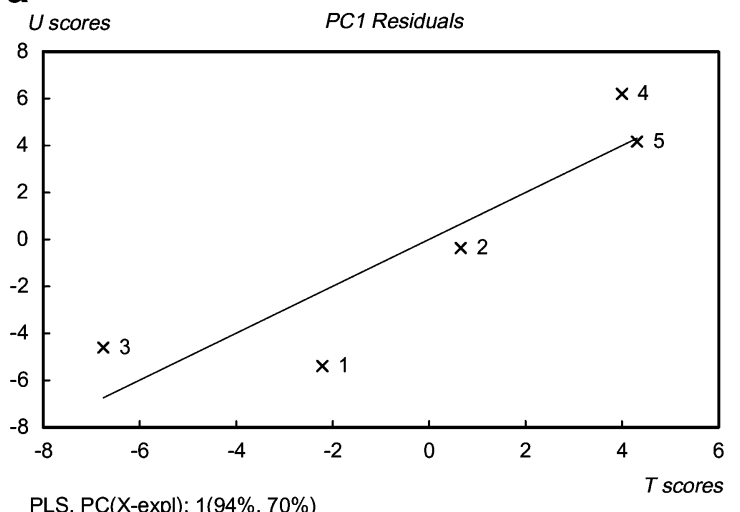

b

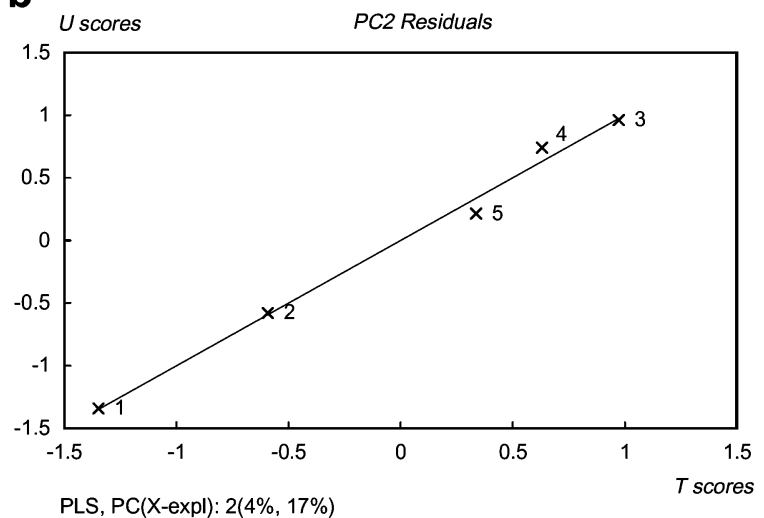

Figure 5. Regression between measured and predicted residuals for (a) $\mathrm{PC}_{1}\left(r^{2}=0.81, p=0.039\right)$ and $(\mathrm{b}) \mathrm{PC} 2\left(r^{2}=0.99, p=0.0003\right)$.

contaminated site for all contaminants apart from As, but the proportion of lighter PAHs and Zn was larger at the other sites. However, analyses of the residuals showed that the model for $\mathrm{PC}_{1}$ (Figure 5a), which explained the separation due to the total contamination level, could not adequately predict the population characteristics for the most contaminated sites (the harbor, site 3), whereas the model for PC2 (Figure 5b), which explained the distribution between contaminants, was much stronger.

\section{Discussion}

The aim of this study was to determine if $O$. pinguis has the potential to be a bioindicator for contamination in the Arctic by investigation of its occurrence and population characteristics at different contaminated and reference sites.

$O$. pinguis in this study was shown to be present also at sites with high contamination, such as the harbor where concentrations of metals and PAHs were within one order of magnitude lower than the measured concentrations in the highly contaminated Boston Harbor (Durell et al., 2008). The Sisimiut harbor sediment concentrations also fall under the categories of "further evaluation for risk" or "risk" when comparing to the EAC values given by the OSPAR Commission (OSPAR, 1997).

The population characteristics of $O$. pinguis could however, not be directly linked to contamination level, as the most contaminated site (the harbor) consisted of a population with the largest body length and dry weight whereas the second most contaminated site (the hospital outlet) consisted of a population with the smallest individuals, more similar in size to the populations found at the reference sites and at the marina.

Besides the differences in contaminant levels, sediment organic matter also varied, with the two most contaminated sites containing a much higher fraction of organic matter than found at the other sites. For amphipods the amount and quality of the organic matter may help in overcoming other stressors (e.g., Costa et al., 2005; Spadaro et al., 2008). The differences in population characteristics may therefore reflect a balance between a positive factor (food availability) and a negative factor (contamination level).

The normalization of the population characteristics to sediment carbon content was an attempt to reduce the confounding influence of food availability on the effect of contamination. The multivariate model then showed a relationship between population characteristics and contamination, albeit with large uncertainties in the prediction. It must also be taken into consideration that contamination levels per se do not necessarily reflect either bioavailability, which can both be reduced and enhanced due to organic enrichment (Gunnarsson et al., 1995), or differ- ences in toxicity between contaminants, and thus the model can not be expected to be conclusive. However, the question of how the actual population characteristics (un-normalized) can vary so much between the two most contaminated sites, still remains. One other reason for the smaller size at the hospital site can be that it is exposed to other contaminants (e.g., pharmaceuticals), that are discharged with the waste water effluent. But, part of the explanation can also be that different population traits and strategies have been selected at these two sites, resulting in different population characteristics, hereunder skewed sex ratios. Selection toward tolerant populations has previously been demonstrated in laboratory exposure systems (e.g., Luoma et al., 1983; Klerks and Levinton, 1989; Galletly et al., 2007; Janssens et al., 2009), where for example Klerks and Levinton (1989) found population-level resistance acquired after only one to four generations in an oligochaete cultured in the presence of cadmium. Anthropogenically impacted sediments are however rarely contaminated with single chemicals, and resistance to contaminant mixtures appears to be more difficult to achieve than resistance to single substances Klerks (1999).

Our results indicate that measuring population characteristics, such as body size and weight, is not sufficient if $O$. pinguis is to be used as a bioindicator. There is a need for consistency in the association between stress and effects as previously suggested ( Adams, 2003; Theodorakis, 2003). Our study does not show such consistency and as discussed by Collier (2003) and Adams (2005), the establishment of the causal relationship between stressors and effects on marine biota is not straightforward in field studies due to the physicochemical and biological complexity of the systems, the range of biotic and abiotic factors that can act on the responses of biota to stressors, and the many pathways by which stressors may affect the ecosystem. However, this study enables us to suggest other relevant endpoints such as reproductive success ( Sundelin and Eriksson, 1998; Strand et al., 2004; Camus and Olsen, 2008) and tolerance. Tolerance can be used as an endpoint, either through comparing the phenotypic response to contaminants of populations from contaminated sites with reference sites, or by comparing genotypic effects on functional genes and total genetic variation ( Street et al., 1998; Bickham et al., 2000; Belfiore and Anderson, 2001; Ross et al., 2002; Gardeström et al., 2006; Hoffmann and Daborn, 2007).

\section{Conclusion}

O. pinguis fulfils the criteria of being a suitable bioindicator for the Arctic in that it has been shown to occur in high numbers in both clean and contaminated areas. The differences in popula- 
tion traits between different types of contaminated areas suggest that the endpoints measured in the present study (body length, amphipod organic content and weight) will need to be supplemented with other endpoints, e.g., reproductive effects, tolerance and genetic diversity, when using this species to assess contamination impacts in complex field settings.

Acknowledgments - We thank Peter Christensen, Roskilde University, for help and guidance with PAH analysis, Martin Larsen and Gitte Jakobsen, NERI, Aarhus University, for metal analysis, Jørgen Berge, UNIS, and Wim Vaders, Tromsø University, for amphipod species identification. We also thank Doris Schiedek for valuable comments on the manuscript. The study was funded by a fellowship from GESS Graduate School, Julie von Müllens Funding and Fabrikat P.A. Fiskers Funding.

\section{References}

Adams, S.M., 2003. Establishing causality between environmental stressors and effects on aquatic ecosystems. Human and Ecological Risk Assessment 9, 17-35.

Adams, S.M., 2005. Assessing cause and effect of multiple stressors on marine systems. Marine Pollution Bulletin 51, 649-657.

Belfiore, N.M., Anderson, S., 2001. Effects of contaminants on genetic patterns in aquatic organisms: A review. Mutation Research 489, 97-122.

Bickham, J.W., Sandhu, S., Hebert, P.D.N., Chikhi, L., Athwal, R., 2000. Effects of chemical contaminants on genetic diversity in natural populations: Implications for biomonitoring and ecotoxicology. $\mathrm{Mu}-$ tation Research 463, 33-51.

Boll, E.S., Christensen, J.H., Holm, P.E., 2008. Quantification and source identification of polycyclic aromatic hydrocarbons in sediment, soil, and water spinach from Hanoi, Vietnam. Journal of Environmental Monitoring 10, 261-269.

Camus, L., Olsen, G.H., 2008. Embryo aberrations in sea ice amphipod Gammarus wilkitzkii exposed to water soluble fraction of oil. Marine Environmental Research 66, 221-222.

Chapman, P.M., Riddle, M.J., 2005. Toxic effects of contaminants in polar marine environments. Environmental Science and Technology May 1, 200A-207A.

Collier, T.K., 2003. Forensic ecotoxicology: Establishing causality between contaminants and biological effects in field studies. Human and Ecological Risk Assessment 9, 259-266.

Conlan, K.E., 1994. Amphipod crustaceans and environmental disturbance: A review. Journal of Natural History 28, 519-554.

Costa, F.O., Neuparth, T., Correia, A.D., Helena Costa, M., 2005. Multilevel assessment of chronic toxicity of estuarine sediments with the amphipod Gammarus locusta: II. Organism and population-level endpoints. Marine Environmental Research 6o, 93-110.

Duquesne, S., Riddle, M.J., Schulz, R., Liess, M., 200o. Effects of contaminants in the Antarctic environment-Potential of the Gammarid amphipod crustacean Paramorea walkeri as a biological indicator for Antarctic ecosystems based on toxicity and bioaccumulation of copper and cadmium. Aquatic Toxicology 49, 131-143.

Durell, G., Pala, S., Field, J., 2008. Sediment contaminants near combined sewer overflows in Dorchester Bay and at other areas in Boston Harbor: 1990-2006. Boston, Massachusetts Water Resources Authority. Report 2008-10, 156pp.

Galletly, B.C., Blows, M.W., Marshall, D.J., 2007. Genetic mechanisms of pollution resistance in a marine invertebrate. Ecological Applications 17, 2290-2297.

Gardeström, J., Gorokhova, E., Gilek, M., Grahn, M., Bengtsson, B.-E., Breitholtz, M., 2006. A multilevel approach to predict toxicity in copepod populations: Assessment of growth, genetics, and population structure. Aquatic Toxicology 79, 41-48.

Gunnarsson, J., Broman, D., Jonsson, P., Olsson, M., Rosenberg, R., 1995. Interactions between eutrophication and contaminants: Towards a new research concept for the European aquatic environment. $A M-$ $\mathrm{BIO} 24,383-385$.

Hoffmann, A.A., Daborn, P.J., 2007. Towards genetic markers in animal populations as biomonitors for human-induced environmental change. Ecology Letters 10, 63-76.

Horner, R., Murphy, D., 1985. Species composition and abundance of zooplankton in the nearshore Beaufort Sea in winter-spring. Arctic 38, 201-209.
Janssens, T.K.S., Roelofs, D., van Straalen, N.M., 2009. Molecular mechanisms of heavy metal tolerance and evolution in invertebrates. Insect Science 16, 3-18.

Jorgensen, E.H., Vijayan, M.M., Killie, J.E.A., Aluru, N., Aas-Hansen, O., Maule, A., 2006. Toxicokinetics and effects of PCBs in Arctic fish: A review of studies on Arctic charr. Journal of Toxicology and Environmental Health - Part A - Current Issues 69, 37-52.

Josefson, A.B., Hansen, J.L.S., Asmund, G., Johansen, P., 2008. Threshold response of benthic macrofauna integrity to metal contamination in West Greenland. Marine Pollution Bulletin 56, 1265-1274.

Klerks, P.L., 1999. Acclimation to contaminants by the grass shrimp Palaemonetes pugio: Individual contaminants vs. mixtures. Ecotoxicology 8, 277-286.

Klerks, P., Levinton, J.S., 1989. Rapid evolution of metal resistance in a benthic oligochaete inhabiting a metal-polluted site. Biological Bulletin 176, 135-141.

Legezynska, J., Weslawski, J.M., Presler, P., 20oo. Benthic scavengers collected by baited traps in the high Arctic. Polar Biology 23, 539-544.

Lockhart, W.L., 1995. Implications of chemical contaminants for aquatic animals in the Canadian Arctic: Some review comments. Science of the Total Environment 160-161, 631-641.

Luoma, S.N., Cain, D.J., Ho, K., Hutchinson, A., 1983. Variable tolerance to copper in 2 species from San-Francisco Bay. Marine Environmental Research 10, 209-222.

Martens, H., Martens, M., 20oo. Modified Jack-knife estimation of parameter uncertainty in bilinear modelling by partial least squares regression (PLSR). Food Quality and Preference 11, 5-16.

Olsen, G.H., Sva, E., Carroll, J., Camus, L., De Coen, W., Smolders, R., Overaas, H., Hylland, K., 2007. Alterations in the energy budget of Arctic benthic species exposed to oil-related compounds. Aquatic Toxicology 83, 85-92.

OSPAR, 1997. Agreed ecotoxicological assessment criteria for trace metals, PCBs, PAHs, TBT and some organochlorine pesticides. Summery Record OSPAR 97/15/1.

Petersen, D.G., Dahllof, I., 2007. Combined effects of pyrene and UVlight on algae and bacteria in an arctic sediment. Ecotoxicology 16, 371-377.

Petersen, D.G., Reichenberg, F., Dahllof, I., 2008. Phototoxicity of pyrene affects benthic algae and bacteria from the arctic. Environmental Science and Technology 42, 1371-1376.

Riget, F., Law, R.J., Hansen, J.C., 2004. The state of contaminants in the Greenland environment. Science of the Total Environment 331, 1-4.

Ross, K., Cooper, N., Bidwell, J.R., John, E., 2002. Genetic diversity and metal tolerance of two marine species: a comparison between populations from contaminated and reference sites. Marine Pollution Bulletin $44,671-679$.

Sainte-Marie, B., 1986a. Effect of bait size and sampling time on the attraction of the lysianassid amphipods Anonyx sarsi (Steele and Brunel) and Orchomenella pinguis (Boeck). Journal of Experimental Marine Biology and Ecology 99, 63-77.

Sainte-Marie, B., 1986b. Feeding and swimming of lysianassid amphipods in a shallow cold-water bay. Marine Biology 91, 219-229.

Sainte-Marie, B., 1991. A review of the reproductive bionomics of aquatic gammaridean amphipods: Variation of life history traits with latitude, depth, salinity and superfamily. Hydrobiologia 223, 189-227.

Spadaro, D., Micevska, T., Simpson, S., 2008. Effect of nutrition on toxicity of contaminants to the epibenthic amphipod Melita plumulosa. Archives of Environmental Contamination and Toxicology 55, 593-602.

Strand, J., Andersen, L., Dahllof, I., Korsgaard, B., 2004. Impaired larval development in broods of eelpout (Zoarces viviparus) in Danish coastal waters. Fish Physiology and Biochemistry 30, 37-46.

Street, G.T., Lotufo, G.R., Montagna, P.A., Fleeger, J.W., 1998. Reduced genetic diversity in a meiobenthic copepod exposed to a xenobiotic. Journal of Experimental Marine Biology and Ecology 222, 93-111.

Sundelin, B., Eriksson, A.K., 1998. Malformations in embryos of the deposit-feeding amphipod Monoporeia affinis in the Baltic Sea. Marine Ecology - Progress Series 171, 165-180.

Theodorakis, C.W., 2003. Establishing causality between population genetic alterations and environmental contamination in aquatic organisms. Human and Ecological Risk Assessment 9, 37-58.

Thomas, J.D., 1993. Biological monitoring and tropical biodiversity in marine environments-A critique with recommendations, and comments on the use of amphipods as bioindicators. Journal of Natural History 27, 795-806.

USEPA, 1994. Inductively Coupled Plasma - Mass Spectrometry (Method 6020). Environmental Protection Agency, Washington, DC. 


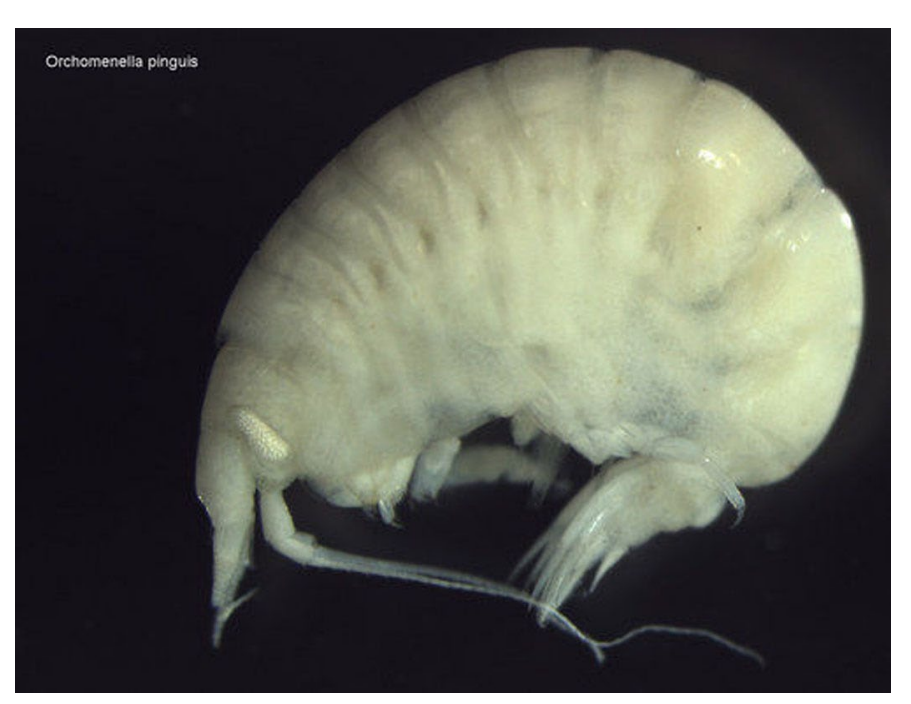

Creative Commons Attribution Non Commercial Share Alike 3.0 (CC BY-NC-SA 3.0)

Some rights reserved

(C) Adriana Radulovici, Biodiversity Institute of Ontario

Supplier: Barcode of Life Data Systems

Photographer: Adriana Radulovici 